\title{
STUDI PENGOLAHAN CUMI-CUMI (Loligo sp.) ASIN KERING DIHUBUNGKAN DENGAN KADAR AIR DAN TINGKAT KESUKAAN KONSUMEN
}

\author{
Anita Hulalata, Daisy M Makapedua dan Rastuti W Paparang
}

Fakultas Perikanan dan Ilmu Kelautan, Universitas Sam Ratulangi, Manado, Sulawesi Utara.

\begin{abstract}
ABSTRAK
Penelitian ini bertujuan untuk mengetahui dan mempelajari tentang pengolahan cumi-cumi (Loligo $s p$ ) asin kering dihubungkan dengan kadar air dan tingkat kesukaan konsumen. Cara perlakuan awal dengan menggunakan alat pengering buatan sumber panas dari sinar matahari dengan lama pengeringan 5 jam dengan suhu $30-31^{\circ} \mathrm{C}$ dan dilanjutkan dengan menggunakan alat pengering buatan sumber panas dari kompor dengan suhu $45-60^{\circ} \mathrm{C}$. Hasil penelitian menunjukkan nilai kadar air cumicumi asin kering pada penelitian ini sudah memenuhi standar mutu SNI (2326:2010) sehingga masih layak untuk dikomersilkan, dengan nilai $20 \%$. Sedangkan dari penelitian ini, nilai kadar air 19,85\% pada lama pengeringan 12 jam dan menggunakan alat pengering buatan dengan sumber panas dari kompor. Berdasarkan uji organoleptik, produk yang paling disukai oleh panelis adalah produk yang diberi perlakuan lama pengeringan selama 12 jam dengan cara pengeringan menggunakan pengering buatan di bawah sinar matahari dan dilanjutkan dengan sumber panas dari kompor yaitu dengan nilai: kenampakan $(8,733)$, bau $(8,533)$, cita rasa $(8,600)$, dan tekstur dengan nilai tertinggi $(8,600)$.
\end{abstract}

Kata kunci: cumi-cumi, Loligo sp., alat pengering buatan, kadar air dan tingkat kesukaan.

\section{PENDAHULUAN}

Cumi-cumi merupakan produk laut yang banyak terdapat di perairan Indonesia. Sebagian besar cumi diolah menjadi bahan makanan protein tinggi. Cumi-cumi memiliki sifat mudah mengalami penurunan mutu sehingga perlu dilakukan pengolahan agar cita rasanya tidak berkurang. Jenis produk olahan cumi-cumi sebagai konsumsi lokal masih terbatas antara lain cumi-cumi kertas, cumi-cumi kering asin, cumi-cumi asap dan cumi-cumi kaleng.

Cumi-cumi memiliki daging putih yang merupakan salah satu kelebihan tersendiri dan disukai oleh masyarakat. Cumi-cumi adalah jenis chepalopoda yang dikenal dalam dunia perdagangan disamping sotong dan gurita. Di bidang perikanan komersial, cumi-cumi merupakan salah satu komoditas perikanan yang cukup penting dan menempati urutan ketiga setelah ikan dan udang (Okuzumi dan Fuji, 2000 dalam Pricilia, 2011).

Di Indonesia tidak semua jenis cumicumi disukai oleh masyarakat untuk di konsumsi segar, karena mempunyai daging yang sangat tebal. Olehkarena itu perlu pengolahan yang menjadikan produk ini lebih menarik(Trilaksani $d k k$., 2004). Cumi olahan merupakan salah satu alternatif yang dapat dibuat dalam pengembangan produk makanan berbahan baku cumi-cumi. Cumi-cumi yang telah mengalami perebusan, pengeringan dan dilanjutkan dengan cara menggoreng agar supaya cumi-cumi tersebut memiliki penampakkan yang menarik dan aromanya yang khas.

Konsumsi makanan yang berasal dari laut seperti cumi-cumi semakin meningkat, setelah adanya kesadaran akan pentingnya bahan makanan tersebut sebagai sumber nutrisi bagi tubuh. Protein, lemak dan komponen lain yang berasal dari makanan hasil laut memiliki keistimewahan tersendiri. Pada cumi-cumi selain dagingnya yang mudah dicerna, juga mengandung asam amino esensial serta kaya akan mineral seperti fosfor dan kalsium yang berguna untuk pertumbuhan dan pembangunan tulang (Meirina, 2008).

Dipasaran internasional cumi-cumi diperdagangkan dalam bentuk beku, asin kering dan kalengan. Sedangkan di Indonesia, cumicumi masih diperdagangkan dalam bentuk segar dan asin kering. Ekspor cumi-cumi segar pada tahun 2001 mencapai 13 ribu ton lebih (senilai US\$ 22 ribu), nilai produksi ekspornya menunjukkan peningkatan yang cukup tajam pada tahun 2005. Tahun 2010 jumlahnya berlipat menjadi 25 ribu ton lebih (senilai lebih dari US\$ 42 ribu). Peningkatan nilai ekspor ini ternyata masih jauh lebih kecil dari 
kebutuhannya di pasar dunia yakni untuk Amerika pada tahun 2010 membutuhkan 640 ribu ton dan Jepang 580 ribu ton, sementara produksi dalam negerinya hanya mampu menghasilkan sekitar 200 ribu ton saja. Dari data tersebut dapat disimpulkan bahwa peluang ekspornya masih terbuka lebar dan cukup menjanjikan (Anonimous, 2011).

Tujuan penelitian ini adalah untuk mengetahui dan mempelajari tentang pengolahan cumi-cumi (Loligo $s p$.) asin kering dihubungkan dengan kadar air dan tingkat kesukaan konsumen.

\section{METODOLOGI PENELITIAN}

Perlakuan yang diberikan pada penelitian ini adalah:

Penelitian ini menggunakan perlakuan awal, dengan cara pengeringan yang dilakukan dengan alat pengering buatan di bawah sinar matahari dengan suhu $30-31^{\circ} \mathrm{C}$ dan sampel tersebut digantung pada pengait yang berada di dalam alat pengering buatan dengan lama pengeringan 5 jam, dimulai dengan lama waktu 10:00-15:00 WITA, dengan suhu yang berkisar $30-31^{\circ} \mathrm{C}$. Selanjutnya dilakukan dengan alat pengering buatan sumber panas dari kompor dengan lama pengeringan $4,8,12$ jam pada suhu $45-60^{\circ} \mathrm{C}$.

Penelitian ini menggunakan rancangan acak lengkap dan disusun secara Faktorial 2x3 dengan $2 \mathrm{x}$ ulangan.

\section{Tata Laksana Penelitian}

Bahan baku cumi-cumi yang digunakan dalam penelitian ini dibeli di pasar tradisional Bersehati Manado sebanyak $6 \mathrm{~kg}$, proses penanganan bahan baku dilakukan dengan cara meletakkan cumi-cumi dalam cool box yang diberi hancuran es dengan ratio perbandingan cumi-cumi dan es adalah 1:2, kemudian sampel dibawa ke Laboratorium Penanganan dan Pengolahan Hasil Perikanan Fakultas Perikanan dan Ilmu Kelautan UNSRAT. Cumi-cumi segar ini dibagi menjadi 2 bagian berdasarkan perlakuan dalam penelitian yang masing-masing sebanyak $3 \mathrm{~kg}$. Ukuran yang digunakan yaitu dengan panjang $\pm 11,91 \mathrm{~cm}$, berat utuh \pm 146 gram dan tebal daging $0,5-1 \mathrm{~cm}$. Bagian yang dikeluarkan adalah kepala, tentakel, kantung tinta, tulang lunak dan isi perut, bagian yang diambil yaitu badannya.

Proses selanjutnya yakni dilakukan pencucian dengan tujuan agar bahan baku yang digunakan dalam penelitian terhindar dari kontaminasi. Air yang digunakan untuk pencucian adalah air bersih yang mengalir. Setelah bahan baku dicuci bersih kemudian dilakukan perendaman dalam larutan garam dengan konsentrasi $15 \%$ dan lama perendaman selama 30 menit dan dilakukan pemasakan awal pada suhu $100^{\circ} \mathrm{C}$ yaitu perebusan dengan larutan garam selama 30 menit. Selanjutnya bahan baku diletakkan pada rak untuk ditiriskan.

Perlakuan awal pengeringan sampel pertama dengan menggunakan alat pengering buatan, sampel digantung pada pengait di dalam alat pengering buatan dan pengeringan dilakukan di bawah sinar matahari, dengan lama pengeringan 5 jam (10:00-15:00 WITA), pada suhu $30-31^{\circ} \mathrm{C}$. Tahapan selanjutnya, sampel di dalam alat pengering tersebut dilanjutkan proses pengeringan dengan alat pengering buatan sumber panas dari kompor, pengeringan dilakukan selama 4,8 , dan 12 jam pada suhu $32-60^{\circ} \mathrm{C}$.

Berbeda dengan perlakuan sebelumnya, sampel kedua dilakukan proses pengeringan menggunakan pengering buatan sumber panas dari kompor (Hock 24 sumbu), dengan lama pengeringan $4,8,12$ jam pada suhu $45-60^{\circ} \mathrm{C}$.

Cumi-cumi asin kering yang telah matang lalu diangkat dan didinginkan. Kemudian dilakukan pengujian Kadar Air dan Organoleptik.

\section{HASIL DAN PEMBAHASAN}

\section{Analisa Kadar Air}

Kadar air merupakan salah satu unsur kimia yang terdapat pada berbagai jenis makhluk hidup termasuk cumi-cumi. Hasil analisa kadar air cumi-cumi yang dilaksanakan dua kali pengulangan bisa dilihat pada Tabel 1 sebagai berikut.

Tabel 1. Data Hasil Analisis Kadar Air CumiCumi (Loligo sp.).

\begin{tabular}{cccccc}
\hline \multicolumn{2}{c}{$\begin{array}{c}\text { Perlakuan } \\
\text { Pengeringan }\end{array}$} & \multicolumn{2}{c}{$\begin{array}{c}\text { Nilai Kadar } \\
\text { Air }\end{array}$} & Total & $\begin{array}{c}\text { Rata } \\
\text {-rata }\end{array}$ \\
\cline { 1 - 4 } Cara & Lama & I & II & & \\
\cline { 1 - 4 } A1 & B1 & 30,43 & 31,31 & 61,74 & 30,87 \\
& B2 & 21,41 & 23,66 & 45,07 & 22,54 \\
& B3 & 19,30 & 19,35 & 38,65 & 19,33 \\
\hline \multirow{2}{*}{ A2 } & B1 & 40,35 & 40,57 & 80,92 & 40,46 \\
& B2 & 28,72 & 26,77 & 55,49 & 27,75 \\
& B3 & 18,90 & 20,27 & 39,17 & 19,59 \\
\hline
\end{tabular}

Berdasarkan hasil tersebut, maka dapat dijelaskan bahwa nilai rata-rata kadar air yang 
tertinggi adalah 40,46\% dengan menggunakan cara pengeringan (A2) yaitu menggunakan alat pengering buatan sumber panas dari kompor dengan lama pengeringan 4 jam. Sedangkan kadar air terendah adalah 19,33\% yaitu pada perlakuan cara pengeringan (A1) yaitu menggunakan pengering buatan dengan lama pengeringan $12 \mathrm{jam}$. Semakin lama pengeringan yang dilakukan, maka kadar air yang terdapat pada tubuh cumi-cumi semakin berkurang.

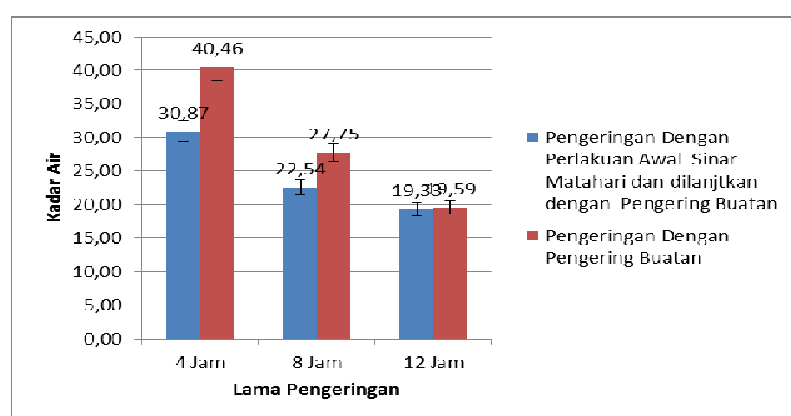

Gambar 1. Hubungan antara lama pengeringan terhadap nilai kadar air cumi-cumi (Loligo sp.) asin kering.

Tabel 2. Data analisa sidik ragam kadar air cumi-cumi (Loligo sp.) asin kering

\begin{tabular}{lrrrrrr}
\hline \multicolumn{1}{c}{$\begin{array}{l}\text { Sumber } \\
\text { Keragaman }\end{array}$} & db & \multirow{2}{*}{ JK } & \multicolumn{1}{c}{ KT } & \multicolumn{1}{c}{ F $_{\text {hitung }}$} & \multicolumn{2}{c}{$\mathbf{F}_{\text {tabel }}$} \\
\hline Perlakuan & 5 & 7101,99 & 1420,40 & 1473,54 & 4,39 & $\mathbf{0 , 1}$ \\
A & 1 & 18,90 & 18,90 & $19,61 * *$ & 5,99 & 13,25 \\
B & 2 & 135,29 & 67,64 & $70,17^{* *}$ & 5,14 & 10,92 \\
AB & 2 & 6947,81 & 3473,90 & $3603,88^{* *}$ & 5,14 & 10,92 \\
Galat & 6 & 5,78 & 0,964 & & & \\
\hline Total & 11 & 7107,78 & & & & \\
\hline Ket.: ** (berbeda sangat nyata) & & & &
\end{tabular}

Tabel 3. Data hasil uji organoleptik kenampakan cumi-cumi (Loligo sp.) asin kering.

\begin{tabular}{|c|c|c|c|c|c|}
\hline \multicolumn{2}{|c|}{$\begin{array}{c}\text { Perlakuan } \\
\text { Pengeringan }\end{array}$} & \multicolumn{2}{|c|}{$\begin{array}{c}\text { Nilai } \\
\text { Organoleptik }\end{array}$} & \multirow[t]{2}{*}{ Total } & \multirow{2}{*}{$\begin{array}{l}\text { Rata- } \\
\text { rata }\end{array}$} \\
\hline Cara & Lama & I & II & & \\
\hline \multirow{3}{*}{$\mathrm{A} 1$} & B1 & 7,13 & 6,53 & 13,67 & 6,83 \\
\hline & B2 & 7,53 & 7,53 & 15,07 & 7,53 \\
\hline & B3 & 9,00 & 8,60 & 17,60 & 8,80 \\
\hline \multirow{3}{*}{ A2 } & B1 & 5,13 & 5,60 & 10,73 & 5,37 \\
\hline & B2 & 7,40 & 7,60 & 15,00 & 7,50 \\
\hline & B3 & 7,93 & 7,80 & 15,73 & 7,87 \\
\hline
\end{tabular}

Dari histogram di atas sangat jelas menunjukkan bahwa lama pengeringan cumicumi memberi pengaruh yang nyata terhadap jumlah kadar air. Artinya penurunan terhadap lama pengeringan selama 12 jam yaitu pada kombinasi perlakuan pengeringan dengan sumber panas dari sinar matahari dan sumber panas dari kompor. Penurunan jumlah kadar air terjadi pada proses pengeringan cumi-cumi disebabkan oleh terjadinya proses penetrasi garam ke dalam tubuh cumi-cumi sehingga menyebabkan keluarnya cairan dari tubuh cumi- cumi karena adanya perbedaan konsentrasi (Afrianto dan Liviawati, 1989).

Dari analisis yang dilakukan oleh Pantouw (2000) pada cumi-cumi asin yang dikeringkan di bawah sinar matahari didapat perbedaan yang sangat nyata antara lama pengeringan dengan jumlah kadar air dimana semakin lama pengeringan semakin rendah jumlah kadar air. Hal ini sama dengan data hasil penelitian ini dan data tersebut memenuhi standar nilai kadar air yang diterapkan pada produk pangan menurut Badan Standardisasi Nasional.

Hasil analisa sidik ragam kadar air cumi-cumi menunjukkan bahwa perbedaan lama waktu pengeringan memberikan pengaruh yang sangat nyata terhadap perbedaan pengurangan kadar air selama pengeringan. Artinya bahwa perbedaan pengurangan kadar air cumi-cumi sangat nyata dipengaruhi oleh lama waktu pengeringan. Beberapa faktor yang menyebabkan produk kehilangan berat adalah lama pengeringan, suhu pengeringan, luas permukaan produk, jenis dan ukuran serta jumlah garam yang diberikan. Ruus (2009) menyatakan bahwa luas permukaan bahan sangat mempengaruhi proses pengeringan, dimana semakin besar luas permukaan bahan jumlah panas yang diterima lebih merata sehingga mempercepat proses pengeringan. Berdasarkan penelitian ini lama pengeringan selama 12 jam sudah mengalami penguapan maksimum namun lama pengeringan 4 dan 8 jam tidak mengakibatkan penguapan kadar air yang berarti. Pada pengeringan 4 jam, kadar air yang dikeluarkan lebih besar atau hampir setengah dari kadar air dalam tubuh cumi-cumi.

\section{Nilai Uji Organoleptik}

Uji organoleptik dilakukan untuk mengetahui tingkat kenampakan dari cumi-cumi dengan cara melihat secara visual hasil akhir dari proses pengeringan yang dilakukan dengan melibatkan berbagai kalangan yang berkompetensi sebagai panelis (Setyaningsih $d k k ., 2010)$. Kegiatan yang dilakukan oleh para panelis meliputi uji kenampakan, bau, rasa dan tekstur dari hasil akhir pengeringan cumi-cumi. Adapun pembahasannya sebagai berikut:

\section{Uji Kenampakan}

Hasil uji kenampakan cumi-cumi yang sudah dikeringkan dapat dilihat pada Tabel 3. Berdasarkan dari data Tabel tersebut dapat 
dijelaskan bahwa nilai rata-rata uji organoleptik kenampakan yang tertinggi adalah 8,80 yaitu pada perlakuan cara pengeringan dengan pengering buatan sumber panas dari kompor dengan lama pengeringan 12 jam. Sedangkan kadar air terendah adalah 5,37 yaitu pada perlakuan cara pengeringan dengan pengering buatan sumber panas dari kompor selama 4 jam.

Hubungan antara nilai uji organoleptik kenampakan dengan cara pengeringan serta lama pengeringan dapat dilihat pada Gambar 2 .

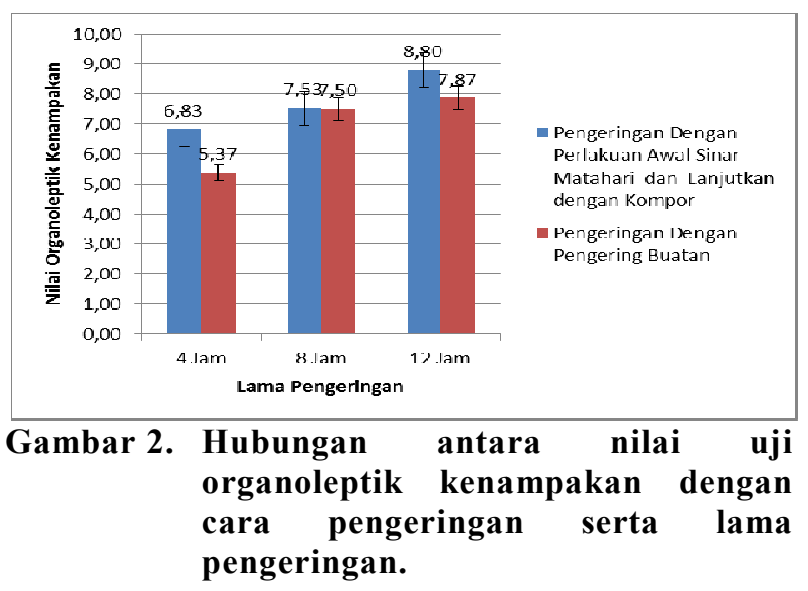

Histogram di atas menjelaskan bahwa hubungan lama pengeringan memberi pengaruh yang sangat nyata terhadap nilai kenampakan dari cumi-cumi asin. Hal ini dapat dilihat pada cara pengeringan menggunakan pengering buatan sumber panas dari sinar matahari dan dilanjutkan dengan pengering buatan sumber panas dari kompor, sehingga didapatkan nilai kenampakan sebesar 8,80 dengan lama pengeringan $12 \mathrm{jam}$. Dengan demikian sangat jelas bahwa lama pengeringan memberikan pengaruh terhadap kenampakan produk, nilai kenampakan 8,80 disukai oleh konsumen.

Hasil penelitian ini menyatakan bahwa semakin rendah jumlah kadar air dari produk cumi-cumi asin maka tingkat kesukaan kenampakan produk tersebut semakin baik. Menurut Winarno (1980), kadar air merupakan komponen penting dalam bahan pangan karena dapat mempengaruhi nilai kenampakan pada produk. Hasil penelitian ini disukai oleh konsumen, dengan lama pengeringan 12 jam dan menggunakan pengering buatan sumber panas dari kompor produk cumi-cumi nampak lebih bersih dan cerah.

Berdasarkan hasil analisa sidik ragam uji organoleptik kenampakan cumi-cumi kering yang diasinkan menunjukkan bahwa perlakuan cara pengeringan dan lama pengeringan yang berbeda memberikan pengaruh berbeda nyata, sedangkan perlakuan perbedaan waktu pengeringan beserta dengan interaksi kedua perlakuan memberikan pengaruh berbeda sangat nyata terhadap nilai kenampakan cumi-cumi yang sudah diasinkan.

\section{Uji Bau}

Hasil uji organoleptik bau cumi-cumi asin kering dapat dilihat pada Tabel 5. Berdasarkan data Tabel 5 tersebut dapat dilihat bahwa nilai rata-rata uji organoleptik bau yang tertinggi adalah 8,73 yaitu pada perlakuan dengan cara pengeringan menggunakan pengeringan buatan dengan sumber panas dari kompor dengan lama pengeringan 12 jam. Sedangkan kadar air terendah adalah 5,43 yaitu pada perlakuan cara pengeringan dengan menggunakan pengering buatan dengan sumber panas dari kompor dengan lama pengeringan 4 jam.

Tabel 4. Data analisa sidik ragam uji organoleptik kenampakan cumi-cumi (Loligo sp.) yang sudah diasinkan.

\begin{tabular}{lrrrrrr}
\hline \multicolumn{1}{c}{$\begin{array}{c}\text { Sumber } \\
\text { Keragaman }\end{array}$} & \multirow{2}{*}{$\mathbf{d b}$} & \multirow{2}{*}{ JK } & \multicolumn{2}{c}{ KT } & \multirow{2}{*}{$\mathbf{F}_{\text {hitung }}$} & \multicolumn{2}{c}{$\mathbf{F}_{\text {tabel }}$} \\
\hline Perlakuan & 5 & 495,04 & 99,01 & 1493,42 & 4,39 & $\mathbf{0 , 1}$ \\
$\mathrm{A}$ & 1 & 0,49 & 0,49 & $7,44 *$ & 5,99 & 13,25 \\
$\mathrm{~B}$ & 2 & 2,55 & 1,28 & $19,26^{* *}$ & 5,14 & 10,92 \\
$\mathrm{AB}$ & 2 & 491,99 & 246,00 & $3710,57 * *$ & 5,14 & 10,92 \\
Galat & 6 & 0,40 & 0,066 & & & \\
\hline Total & 11 & 495,44 & & & & \\
\hline Ket.: *(berbeda nyata) dan ** (berbeda sangat nyata).
\end{tabular}

Tabel 5. Data hasil uji organoleptik bau cumicumi (Loligo sp.) asin kering.

\begin{tabular}{cccccc}
\hline \multicolumn{2}{c}{$\begin{array}{c}\text { Perlakuan } \\
\text { Pengeringan }\end{array}$} & $\begin{array}{c}\text { Nilai Organoleptik } \\
\text { Bau }\end{array}$ & Total & $\begin{array}{c}\text { Rata- } \\
\text { rata }\end{array}$ \\
\cline { 1 - 4 } Cara & Lama & I & II & & \\
\cline { 1 - 2 } A1 & B1 & 7,13 & 6,73 & 13,87 & 6,93 \\
& B2 & 7,33 & 7,33 & 14,67 & 7,33 \\
& B3 & 8,80 & 8,67 & 17,47 & 8,73 \\
\hline \multirow{3}{*}{ A2 } & B1 & 5,13 & 5,73 & 10,87 & 5,43 \\
& B2 & 7,27 & 7,20 & 14,47 & 7,23 \\
& B3 & 7,73 & 7,87 & 15,60 & 7,80 \\
\hline
\end{tabular}

Hubungan antara nilai uji organoleptik bau dengan cara pengeringan serta lama pengeringan dapat dilihat pada Gambar 4. Histogram pada gambar 4 ini menjelaskan bahwa lama pengeringan mempengaruhi nilai bau dari cumi-cumi yang telah dikeringkan, pada penurunan lama pengeringan 4 jam dan memakai cara pengeringan buatan sumber panas dari kompor 24 sumbu semakin lama waktu pengeringan maka nilai bau tersebut akan semakin tinggi pula. Semakin tingginya nilai bau disebabkan oleh semakin kurangnya kadar air dalam daging cumi-cumi. 


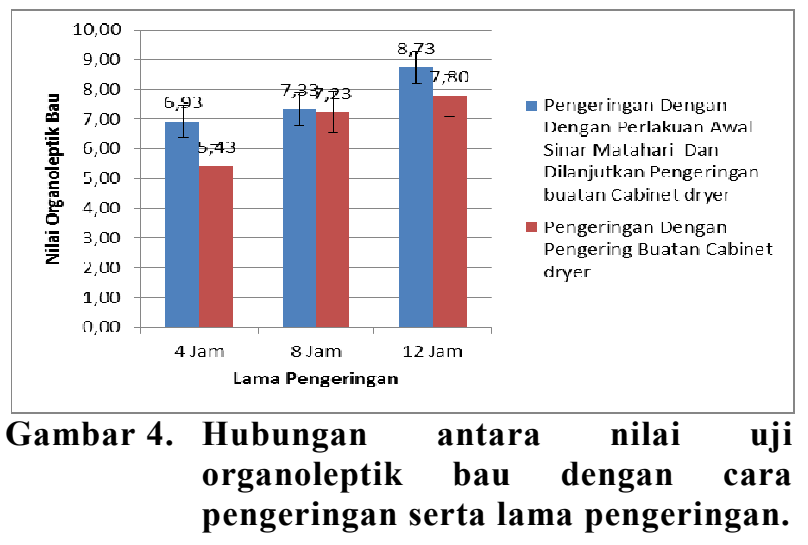

Menurut Afrianto dan Liviawati (1989) Hampir sebagian besar tubuh ikan mengandung banyak air sehingga media yang sangat cocok bagi pertumbuhan bakteri pembusuk maupun kadar air di dalam tubuh ikan aktivitas bakteri akan terhambat sehingga proses pembusuk dapat dicegah, pengurangan kadar air dari dalam tubuh ikan dapat dilakukan dengan beberapa cara.

Tabel 6. Data analisa sidik ragam uji organoleptik bau cumi-cumi (Loligo sp.) asin kering.

\begin{tabular}{lrrrrrr}
\hline \multicolumn{2}{c}{$\begin{array}{l}\text { Sumber } \\
\text { Keragaman }\end{array}$} & Db & \multicolumn{1}{c}{ JK } & \multicolumn{1}{c}{ KT } & \multicolumn{1}{c}{$\mathbf{F}_{\text {hitung }}$} & \multicolumn{2}{c}{$\mathbf{F}_{\text {tabel }}$} \\
\hline Perlakuan & 5 & 484,16 & 96,83 & 2074,97 & 4,39 & $\mathbf{0 , 1}$ \\
A & 1 & 0,53 & 0,53 & $11,46 *$ & 5,99 & 13,25 \\
B & 2 & 2,17 & 1,09 & $23,28 * *$ & 5,14 & 10,92 \\
AB & 2 & 481,45 & 240,73 & $5158,41 * *$ & 5,14 & 10,92 \\
Galat & 6 & 0,28 & 0,047 & & & \\
\hline Total & 11 & 484,44 & & & & \\
\hline Ket.: *(berbeda nyata) dan ** (berbeda sangat nyata).
\end{tabular}

Tabel 7.Data hasil uji organoleptik rasa cumicumi (Loligo sp.) asin kering

\begin{tabular}{|c|c|c|c|c|c|}
\hline \multicolumn{2}{|c|}{$\begin{array}{l}\text { Perlakuan } \\
\text { Pengeringan }\end{array}$} & \multicolumn{2}{|c|}{$\begin{array}{c}\text { Nilai Organoleptik } \\
\text { Rasa }\end{array}$} & \multirow[t]{2}{*}{ Total } & \multirow{2}{*}{$\begin{array}{l}\text { Rata- } \\
\text { rata }\end{array}$} \\
\hline Cara & Lama & I & II & & \\
\hline \multirow{3}{*}{$\mathrm{A} 1$} & B1 & 7,13 & 7,07 & 14,20 & 7,10 \\
\hline & B2 & 7,40 & 7,73 & 15,13 & 7,57 \\
\hline & B3 & 9,00 & 8,87 & 17,87 & 8,93 \\
\hline \multirow{3}{*}{ A2 } & B1 & 5,47 & 5,93 & 11,40 & 5,70 \\
\hline & B2 & 7,47 & 7,20 & 14,67 & 7,33 \\
\hline & B3 & 8,13 & 8,00 & 16,13 & 8,07 \\
\hline
\end{tabular}

Pantouw (2000) menyatakan bahwa mikroba akan merusak protein yang menghasilkan bau busuk karena terjadi pemecahan asam-asam amino. Pada penelitian ini dilakukan nilai organoleptik pada bau, di dapatkan nilai yang lebih tinggi pada perlakuan pengeringan dengan waktu yang lama tetapi cara pengeringan tersebut dilakukan dengan cara pengeringan dengan sumber panas dari kompor. Hal ini dimaksudkan agar supaya kandungan air yang terdapat di dalam tubuh cumi cepat mengalami penguapan sehingga terhindar dari aroma bau yang tidak diinginkan oleh para panelis nantinya. Berdasarkan hasil analisa sidik ragam menunjukkan bahwa lama pengeringan selama 4 jam dan menggunakan pengeringan buatan sumber panas dari kompor memberikan pengaruh yang berbeda nyata, sedangkan perlakuan dengan perbedaan waktu pengeringan dan interaksi kedua perlakuan memberikan pengaruh yang sangat nyata terhadap nilai bau cumi-cumi.

\section{Uji Rasa}

Hasil uji organoleptik rasa cumi-cumi yang diasinkan dapat dilihat pada Tabel 7 . Berdasarkan data tersebut di atas dapat dilihat bahwa nilai rata-rata uji organoleptik rasa yang tertinggi adalah 8,93 yakni pada perlakuan lama pengeringan 12 jam dengan cara pengeringan menggunakan pengering buatan sumber panas dari kompor (A1). Hubungan antara nilai uji organoleptik rasa dengan cara pengeringan serta lama pengeringan dapat dilihat pada Gambar 5.

Dari Gambar 5 menunjukkan bahwa lama pengeringan dapat mempengaruhi nilai rasa dari cumi-cumi asin, yaitu semakin lama proses pengeringan maka semakin tinggi nilai rasa tersebut. Pengurangan kadar air dalam tubuh cumi-cumi dipengaruhi oleh lamanya perlakuan pengeringan. Hal ini disebabkan karena selama proses pengeringan berlangsung cumi-cumi akan menerima panas sehingga kadar air dalam bahan akan menguap.

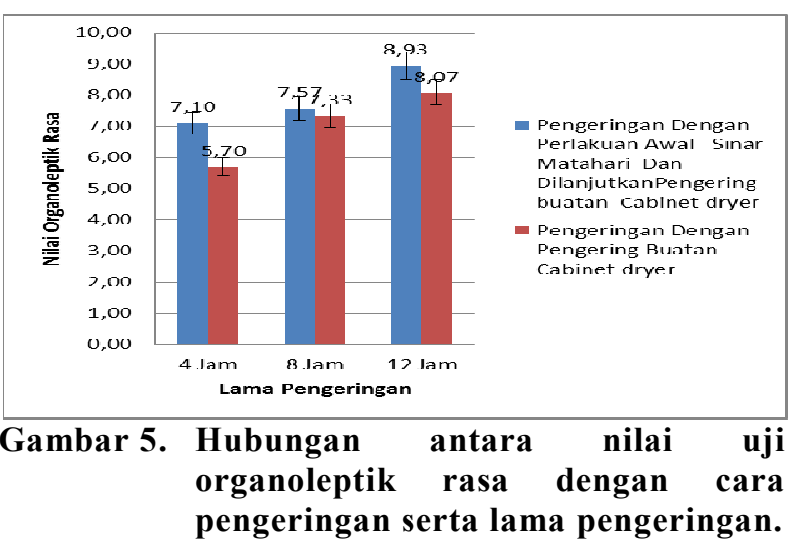

Berdasarkan Gambar 5 di atas menunjukkan bahwa lama pengeringan dapat mempengaruhi nilai rasa dari cumi-cumi asin, yaitu semakin lama proses pengeringan maka semakin tinggi nilai rasa tersebut. Pengurangan kadar air dalam tubuh cumi-cumi dipengaruhi oleh lamanya perlakuan pengeringan. Hal ini disebabkan karena panas sehingga kadar air dalam bahan akan menguap. Pada penelitian ini 
lakukan nilai organoleptik pada cita rasa di dapat nilai yang lebih tinggi pada perlakuan pengeringan dengan lama 12 jam dengan pengeringan sumber panas dari kompor .

Menurut Hadiwiyoto (1993) perubahan cita rasa disebabkan oleh perubahan-perubahan biokimia (penguraian protein dan lemak) pada daging cumi-cumi. Sedangkan Buckle, et al. (1987) dalam Pantouw (2000), menyatakan bahwa penyimpanan dapat merubah cita rasa, karena dengan adanya penyimpanan bahan pangan akan mengalami reaksi atau perubahan sifat fisik, kimia dan organoleptik.

Tabel 8. Data analisa sidik ragam uji organoleptik rasa cumi-cumi (Loligo sp.) asin kering.

\begin{tabular}{lrrrrrr}
\hline \multicolumn{1}{c}{$\begin{array}{c}\text { Sumber } \\
\text { Keragaman }\end{array}$} & Db & \multicolumn{1}{c}{ JK } & \multicolumn{1}{c}{ KT } & \multirow{2}{*}{ F $_{\text {hitung }}$} & \multicolumn{2}{c}{$\mathbf{F}_{\text {tabel }}$} \\
\hline Perlakuan & 5 & 511,11 & 102,22 & 2787,86 & 4,39 & \multicolumn{1}{c}{8,75} \\
A & 1 & 0,52 & 0,52 & $14,20^{* *}$ & 5,99 & 13,25 \\
B & 2 & 2,20 & 1,10 & $30,07^{* *}$ & 5,14 & 10,92 \\
AB & 2 & 508,38 & 254,19 & $6932,48^{* *}$ & 5,14 & 10,92 \\
Galat & 6 & 0,22 & 0,037 & & & \\
\hline Total & 11 & 511,33 & & & & \\
\hline \multicolumn{7}{l}{ Ket.: ** (berbeda sangat nyata). }
\end{tabular}

Tabel 9. Data hasil uji organoleptik tekstur cumi-cumi (Loligo sp.) asin kering.

\begin{tabular}{cccccc}
\hline \multicolumn{2}{c}{$\begin{array}{c}\text { Perlakuan } \\
\text { Pengeringan }\end{array}$} & $\begin{array}{c}\text { Nilai organoleptik } \\
\text { tekstur }\end{array}$ & Total & $\begin{array}{c}\text { Rata- } \\
\text { rata }\end{array}$ \\
\cline { 1 - 4 } Cara & Lama & I & II & & \\
\cline { 1 - 2 } A1 & B1 & 6,87 & 6,73 & 13,60 & 6,80 \\
& B2 & 7,27 & 7,40 & 14,67 & 7,33 \\
& B3 & 8,47 & 8,40 & 16,87 & 8,43 \\
\hline \multirow{3}{*}{ A2 } & B1 & 6,00 & 6,00 & 12,00 & 6,00 \\
& B2 & 7,07 & 7,20 & 14,27 & 7,13 \\
& B3 & 7,53 & 7,87 & 15,40 & 7,70 \\
\hline
\end{tabular}

Berdasarkan hasil analisa sidik ragam menunjukkan bahwa lama pengeringan dan lama perbedaan waktu pengeringan selama 4 jam dengan menggunakan pengering buatan sumber panas dari kompor memberikan pengaruh berbeda sangat nyata. Sedangkan pada interaksi kedua perlakuan memberikan pengaruh berbeda sangat nyata terhadap nilai cita rasa cumi-cumi asin kering.

\section{Tekstur}

Hasil uji organoleptik Tekstur cumicumi asin dapat dilihat pada Tabel 9. Berdasarkan data Tabel 9 di bawah ini dapat dilihat bahwa nilai rata-rata uji organoleptik tekstur yang tertinggi adalah 8,43 yaitu pada perlakuan cara pengeringan menggunakan pengering buatan sumber panas dari kompor dengan lama pengeringan $12 \mathrm{jam}$.
Hubungan antara nilai uji organoleptik tekstur dengan cara pengeringan serta lama pengeringan dapat dilihat pada Gambar 6 di bawah ini. Gambar histogram di atas dapat menjelaskan bahwa hubungan lama pengeringan memberi pengaruh yang berbeda sangat nyata terhadapa nilai tekstur dari cumi-cumi asin. Hal ini dapat dilihat pada cara pengering buatan (A2) sehingga didapatkan nilai tekstur sebesar 8,43 dengan lama pengeringan 12 jam.

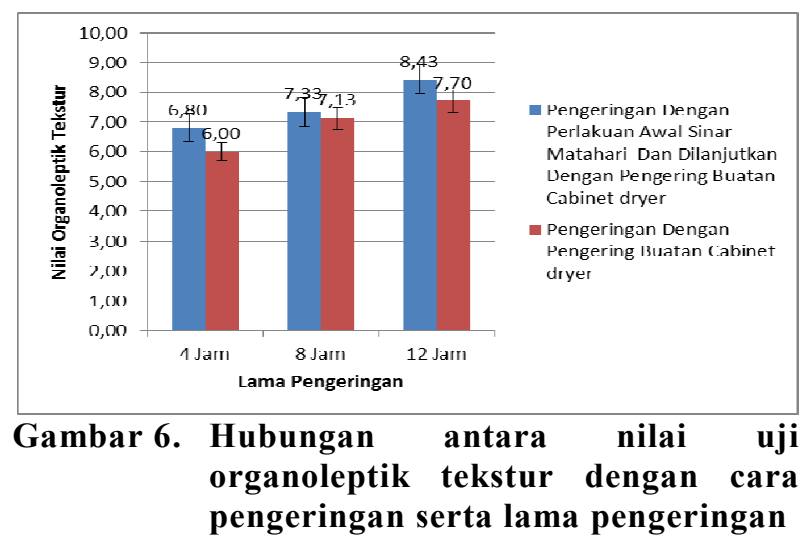

(2009)

Berdasarkan hasil penelitian Ruus konsentrasi garam yang semakin tinggi dan semakin lama waktu pengeringan akan lebih besar menurunkan kadar air dari dalam tubuh ikan. Hal ini disebabkan karena selama proses pengeringan, ikan menerima panas sehingga kadar air dalam produk ikan asin tersebut maka akan membuat tekstur dari produk ikan asin lebih baik. Hasil penelitian ini menunjukkan bahwa nilai yang paling tinggi pada perlakuan lama pengeringan 12 jam pengeringan buatan sumber panas dari kompor. Oleh karena itu dapat dinyatakan bahwa lama pengeringan dan jumlah kadar air dapat mempengaruhi tingkat kesukaan konsumen terhadap cumi-cumi asin kering dan lebih disukai oleh konsumen. Menurut Buckle et al. (1987) dalam Pantouw (2000), bahwa pertumbuhan mikroba pada makanan dapat mengakibatkan perubahan fisik maupun kimia yang tidak diinginkan.

Tabel 10. Data analisa sidik ragam uji organoleptik tekstur cumi-cumi (Loligo sp.) asin kering.

\begin{tabular}{|c|c|c|c|c|c|c|}
\hline \multirow{2}{*}{$\begin{array}{c}\text { Sumber } \\
\text { Keragaman }\end{array}$} & \multirow{2}{*}{ db } & \multirow{2}{*}{ JK } & \multirow{2}{*}{ KT } & \multirow{2}{*}{ F hitung } & \multicolumn{2}{|c|}{ F tabel } \\
\hline & & & & & 0,5 & 0,1 \\
\hline Perlakuan & 5 & 477,66 & 95,53 & 6787,85 & 4,39 & 8,75 \\
\hline A & 1 & 0,25 & 0,25 & $17,79 * *$ & 5,99 & 13,25 \\
\hline B & 2 & 1,39 & 0,69 & $49,34 * *$ & 5,14 & 10,92 \\
\hline $\mathrm{AB}$ & 2 & 476,02 & 238,01 & $16911,38 * *$ & 5,14 & 10,92 \\
\hline Galat & 6 & 0,08 & 0,014 & & & \\
\hline Total & 11 & 477,75 & & & & \\
\hline
\end{tabular}


Seperti pada uji organoleptik cita rasa, uji organoleptik tekstur berdasarkan hasil analisa sidik ragam menunjukkan bahwa lama pengeringan selama 4 jam dan menggunakan pengering buatan dengan sumber panas dari kompor dan perlakuan pengeringan dengan waktu yang berbeda memberikan pengaruh berbeda sangat nyata, sedangkan interaksi dari kedua perlakuan memberikan pengaruh yang sangat nyata terhadap nilai konsistensi cumicumi asin kering.

\section{KESIMPULAN DAN SARAN}

Berdasarkan penelitian tentang studi pengolahan cumi-cumi (Loligo $s p$.) asin kering yang dihubungkan dengan kadar air dan tingkat kesukaan konsumen, maka dapat ditarik kesimpulan sebagai berikut:

1. Nilai kadar air cumi-cumi asin kering pada penelitian ini sudah memenuhi standar mutu cumi-cumi asin kering berdasarkan SNI (2326:2010) sehingga layak untuk dikomersialkan, dengan nilai $20 \%$. Sedangkan yang didapat dalam penelitian ini dalam nilai kadar air $19,85 \%$ dengan lama pengeringan 12 jam dan menggunakan pengering buatan dengan sumber panas dari kompor dan nilai tersebut memenuhi standar SNI.

2. Berdasarkan uji organoleptik, produk yang paling disukai oleh panelis adalah produk yang diberi perlakuan lama pengeringan selama 12 jam dengan cara pengeringan dengan pengering buatan menggunakan perlakuan awal di bawah sinar matahari dan dilanjutkan dengan sumber panas dari kompor yaitu dengan nilai kenampakan (8.733), bau $(8,533)$, cita rasa $(8,600)$, dan konsisten dengan nilai tertinggi $(8,600)$.

Disarankan perlu penelitian lanjut tentang pengemasan yang beragam dan memenuhi standar sanitasi dan higienis, serta uji mikrobiologi TPC dan kapang pada cumicumi asin kering.

\section{DAFTAR PUSTAKA}

Anonimous. 2001. Informasi Cumi-cumi. Direktorat Prasarana Perikanan Tangkap. Departemen Kelautan dan Perikanan. Jakarta.

Anonimous, 2011. Agromaret-com/artikel-Rangsangcumicumi-bertelur.20 Febuary,2013.

Afrianto E. dan Liviawati. E. 1989. Pengawetan dan Pengolahan Ikan. Kanisius. Yogyakarta.
Ahmad dan Thabrani. 2009. Klasifikasi dan Struktur Anatomi Molusca. http://asatrio.blogspot.com/2009/ 11/laporan-prakikum-biologi-klasifikasi.html. 7 Agustus 2012, Pukul 06.30 Wita.

Badan Standar Nasional 2006. Standar Nasional Indonesia (SNI) Penentuan Kadar Air Pada Produk Perikanan. Jakarta.

Badan Standar Nasional. 2011. Standar Nasional Indonesia (SNI) Petunjuk Pengujian Organoleptik Atau Sensori Pada Produk Perikanan. Jakarta.

Berhimpon, S. dan Ishak E. 1987. Beberapa Potensi Perikanan dalam Pengolahan dan Penyimpanan Ikan Asin Kering. Department Food Science and Technology School of Biological Technologies The University of New South Wales.

Buckle K.A., Edwards R.A., Fleet, G. H., Wooton M., 1987. Ilmu Pangan. Penerbit UI- Press. Jakarta.

Bintang Y., 2012 Konstruksi dan Kapasitas Alat Pengeringan Ikan Surya Sistem Bongkar Pasang. Skripsi Fakultas Perikanan Dan Ilmu Kelautan, Universitas Sam Ratulangi Manado.

Hadiwiyoto S., 1993. Teknologi Hasil Perikanan Jilid 1. Fakultas Teknologi Perikanan, Universitas Gajah Mada. Jogjakarta.

Harikedua J.W., 1985. Dasar-dasar Pengawetan dan Pengolahan Pangan. Fakultas Perikanan UNSRAT. Manado.

Harikedua, J.W., Kaseger B., Sanger G., Setyaningsih L., Sinyal A., Pandey E., dan Dolonseda S., 1991. Pengantar Pengolahan Hasil Perikanan. Fakultas Perikanan, Universitas Sam Ratulangi. Manado.

Ilyas S., 1972. Pengantar Pengolahan Ikan. Lembaga Penelitian Teknologi Perikanan. Jakarta.

Meirina Kurnia., 2008. Kajian Pengolahan Cumi-cumi (Loligo sp) Siap Saji. Skripsi. Fakultas Teknologi Pertanian, Institut Pertanian Bogor.

Moeljanto, R., 1982. Penggaraman dan Ilmu Pengeringan Ikan. Penerbit PT. Penebar Swadaya Jakarta.

Moeljanto R. 1992. Pengawetan dan Pengolahan Hasil Perikanan, Penerbit PT. Penebar Swadaya. Jakarta.

Pantouw R. F.2000. Pengaruh Lama Penyimpanan Pada Suhu Kamar Terhadap Mutu Cumi-Cumi (Loligo sp.) Asin Kering. Skripsi. Fakultas Perikanan dan Ilmu Kelautan, Universitas Sam RatulangiManado.

Pricilia V.2011. Karakterisasi Cumi-Cumi (Loligo sp.). Departemen Teknologi Hasil Perairan, Fakultas Perikanan dan Ilmu Kelautan, Institut Pertanian Bogor. http://www.scribd.com/doc/82267918/jurnalcumi-pipirijiin. Manado Senin, 6 Agustus 2012, Pukul 22:00

Ruus. O.V.2009. Pengaruh Konsentrasi Larutan Garam dan Lama Pengeringan Terhadap Mutu Ikan Layang (Decapterus sp) Asin dengan Kadar Garam Rendah. Skripsi. Fakultas Perikanan dan Ilmu Kelautan Universitas Sam Ratulangi. Manado.

Setyaningsih D; Anton A; Maya P.S. 2010. Analisis Sensori Untuk Industri Pangan dan Agro. IPB Press. Bogor.

Trilaksani. W., Gerungan. A., dan Mardi. S., 2004. Pengaruh Suhu dan Lama Pengovenan Terhadap Karakteristik Cumi-cumi (Loligo sp.) Kertas. Buletin Teknologi Hasil Perikanan. Volume III 
Wirnarno F.G. 1980., Pengantar Teknologi Pangan. PT. Wirnarno F.G., 1989. Kimia Pangan Dan Gizi. PT. Gramedia, Jakarta Gramedia. Jakarta. 